The Canadian Mineralogist

Vol. 41, pp. 721-725 (2003)

\title{
ARTSMITHITE, A NEW $\mathrm{Hg}^{1+}$-AI PHOSPHATE-HYDROXIDE FROM THE FUNDERBURK PROSPECT, PIKE COUNTY, ARKANSAS, U.S.A.
}

\author{
ANDREW C. ROBERTS $§$ \\ Geological Survey of Canada, 601 Booth Street, Ottawa, Ontario K1A OE8, Canada \\ Mark A. COOPER and Frank C. HAWTHORNE \\ Department of Geological Sciences, University of Manitoba, Winnipeg, Manitoba R3T 2N2, Canada \\ Robert A. GAULT AND Joel D. GRICE \\ Canadian Museum of Nature, P.O. Box 3443, Station D, Ottawa, Ontario K1P 6P4, Canada
}

ANTHONY J. NIKISCHER

Excalibur Mineral Company, 1000 North Division Street, Peekskill, New York 10566-1830, U.S.A.

\begin{abstract}
Artsmithite, with the general formula $\mathrm{Hg}^{1+}{ }_{4} \mathrm{Al}\left(\mathrm{PO}_{4}\right)_{2-x}(\mathrm{OH})_{1+3 x}(x=0.26)$, is monoclinic, $C 2 / c$, with the following unit-cell parameters measured on a single-crystal X-ray diffractometer: $a$ 17.022(5), $b$ 9.074(2), $c 7.015(2) \AA, \beta 101.20(1)^{\circ}, V 1062.9(8)$ $\AA^{3} ; a: b: c$ 1.8759:1:0.7731, $Z=4$. The strongest eight lines of the X-ray powder-diffraction pattern $[d$ in $\AA(I)(h k l)]$ are: 8.326(100)(200), 4.739(50)(310), 4.166(40)(400), 2.979(80)(202), 2.952(50)(402), 2.784(80)(600), 2.660(75)(330) and $1.755(50)(\overline{7} 32,640, \overline{2} 04)$. The mineral occurs as a colorless-to-white matted nest, approximately $3 \times 1 \mathrm{~mm}$ in size, of randomly scattered fibrous to acicular crystals at the Funderburk prospect, Pike County, Arkansas, U.S.A. Associated minerals on the holotype specimen are quartz, goethite, dickite and cinnabar; other minerals reported from the locality include barite, calcite, calomel, eglestonite, fluorapatite, galena, livingstonite, native mercury, metacinnabar, montroydite, perhamite, pyrite, siderite, stibiconite, stibnite and terlinguaite. Artsmithite is a secondary phase most probably formed from the breakdown of primary cinnabar and apatite. Individual needles are elongate [001], colorless, transparent, with a length-to-width ratio in excess of 100:1, and they average about $0.5 \mathrm{~mm}$ in length. Artsmithite is vitreous, with an off-white to cream streak, no obvious cleavage, irregular fracture; it is nonfluorescent, and the needles are flexible. $D$ (calc.) is $6.40 \mathrm{~g} / \mathrm{cm}^{3}$ for the formula inferred from the crystal-structure analysis. It is biaxial positive, and all indices of refraction exceed $1.80 ; 2 V$ (meas.) $60^{\circ} ; r<v$, distinct; length slow with $Z \approx c$. An electron-microprobe analysis gave $\mathrm{Hg}_{2} \mathrm{O}$ 78.28, $\mathrm{Al}_{2} \mathrm{O}_{3}$ 5.02, $\mathrm{P}_{2} \mathrm{O}_{5} 11.39, \mathrm{H}_{2} \mathrm{O}$ [1.63], total [96.32] wt.\%. The empirical formula, derived from the results of the crystal-structure and electron-microprobe analysis, is $\mathrm{Hg}^{1+}{ }_{4.00} \mathrm{Al}_{1.05} \mathrm{P}_{1.71} \mathrm{O}_{8.74} \mathrm{H}_{1.78}$, on the basis of $\mathrm{O}=8.74$ and $(\mathrm{OH})=1.78$ (from crystal structure). The infrared-absorption spectrum shows bands for structural $(\mathrm{OH})$, adsorbed $\left(\mathrm{H}_{2} \mathrm{O}\right)$ and phosphate. The name honors Arthur E. Smith, Jr., of Houston, Texas, who collected the mineral specimen in 1995.
\end{abstract}

Keywords: artsmithite, new mineral species, mercury-aluminum phosphate-hydroxide, X-ray data, electron-microprobe data, infrared spectroscopy, Funderburk prospect, Pike County, Arkansas, U.S.A.

\section{SOMMAIRE}

La artsmithite, dont la formule générale est $\mathrm{Hg}^{1+}{ }_{4} \mathrm{Al}\left(\mathrm{PO}_{4}\right)_{2-x}(\mathrm{OH})_{1+3 x}(x=0.26)$, est monoclinique, $C 2 / c$, avec les paramètres réticulaires suivants, déterminés sur cristal unique avec un diffractomètre: $a 17.022(5), b 9.074(2), c 7.015(2) \AA, \beta 101.20(1)^{\circ}, V$ $1062.9(8) \AA^{3} ; a: b: c$ 1.8759:1:0.7731, $Z=4$. Les huit raies les plus intenses du spectre de diffraction obtenu sur poudre $[d$ en $\AA(I)(h k l)]$ sont: 8.326(100)(200), 4.739(50)(310), 4.166(40)(400), 2.979(80)(202), 2.952(50)( $\overline{402}), 2.784(80)(600)$, $2.660(75)(330)$ et $1.755(50)(\overline{7} 32,640, \overline{2} 04)$. Le minéral se présente en amas de cristaux aciculaires incolores ou blancs non orientés, mesurant environ $3 \times 1 \mathrm{~mm}$, à l'indice Funderburk, comté de Pike, en Arkansas, aux Etats-Unis. Lui sont associés sur l'échantillon holotype: quartz, goethite, dickite et cinnabre; on a aussi trouvé barite, calcite, calomel, eglestonite, fluorapatite, galène, livingstonite, mercure natif, métacinnabre, montroydite, perhamite, pyrite, sidérite, stibiconite, stibnite et terlinguaïte à cet endroit. La artsmithite est une phase secondaire, tout probablement le résultat d'une déstabilisation du cinnabre et de la fluorapatite. Les

§E-mail address: aroberts@nrcan.gc.ca 
cristaux aciculaires sont allongés sur [001], incolores, transparents, avec un rapport de longueur à largeur de 100:1, et ils atteignent environ $0.5 \mathrm{~mm}$ en longueur. Le minéral possède un aspect vitreux, une rayure blanc crèmeux, une fracture irrégulière, et semble sans clivage et sans fluorescence. Les cristaux sont flexibles. La densité mesurée est $6.40 \mathrm{~g} / \mathrm{cm}^{3}$ pour la formule découlant de l'ébauche de la structure cristalline. La artsmithite est biaxe positive, et les indices de réfraction dépassent tous $1.80 ; 1$ 'angle $2 \mathrm{~V}$ (mesuré) est $60^{\circ}$, et $r<v$, distinct; l'allongement est positif, avec $Z \approx c$. Une analyse à la microsonde électronique a donné: $\mathrm{Hg}_{2} \mathrm{O}$ 78.28, $\mathrm{Al}_{2} \mathrm{O}_{3}$ 5.02, $\mathrm{P}_{2} \mathrm{O}_{5}$ 11.39, $\mathrm{H}_{2} \mathrm{O}$ [1.63], pour un total de [96.32]\% (en poids). La formule empirique, dérivée à partir des résultats de l'ébauche de la structure cristalline et des données provenant de la microsonde électronique, est $\mathrm{Hg}^{1+}{ }_{4.00} \mathrm{Al}_{1.05} \mathrm{P}_{1.71} \mathrm{O}_{8.74} \mathrm{H}_{1.78}$, calculée sur une base de $\mathrm{O}=8.74$ et $(\mathrm{OH})=1.78$ (information obtenue de l'étude structurale). Le spectre d'absorption infrarouge montre des bandes attrribuées aux groupes hydroxyle, aux molécules de $\mathrm{H}_{2} \mathrm{O}$ absorbées et aux groupes phosphate. Le nom honore Arthur E. Smith, Jr., de Houston, Texas, qui en a fait la découverte en 1995.

(Traduit par la Rédaction)

Mots-clés: artsmithite, nouvelle espèce minérale, phosphate-hydroxyde de mercure et aluminium, diffraction X, données de microsonde électronique, spectroscopie infrarouge, indice de Funderburk, comté de Pike, Arkansas, Etats-Unis.

\section{INTRODUCTION}

The Funderburk prospect, originally opened in 1932 by C.I. Barfield on land owned by J.H. Funderburk (Reed \& Wells 1938), is one of a series of Hg-bearing prospects and mines situated within Pike County, Arkansas, U.S.A. The mercury anomalies are spatially clustered on the flank of Skeleton Mountain, along the north shore of nearby Lake Greeson, and on islands adjacent to the east side of the lake. The Funderburk locality is generally regarded as a prospect, but the presence of extensive overgrown dumps and the occasional find of high-grade ore suggest production of substantial quantities of mercury. All specimens of the new $\mathrm{Hg}$ bearing mineral species were collected in 1995 from a one meter-sized boulder found on the dump.

The mineral is named artsmithite in honor of Arthur (“Art”) E. Smith, Jr. (b. 1935), a petroleum geologist from Houston, Texas, who collected the material in which the new species was found; he noted some unusual nests of crystals that have turned out to be new to Science. He has been an avid mineral collector and micromounter since 1956, and specializes in Arkansas and Texas minerals. The mineral and mineral name have been approved by the Commission on New Minerals and Mineral Names, IMA (\#2002-39). The holotype specimen $(2 \times 1.5 \times 1 \mathrm{~cm})$, electron-microprobe mount used for quantitative electron-microprobe study, and several single-crystal mounts, are preserved in the Systematic Reference Series of the National Mineral Collection at the Geological Survey of Canada, Ottawa, Ontario, catalogue number NMCC68092.

\section{Occurrence and Associated Minerals}

The Funderburk prospect (lat. $34.177^{\circ} \mathrm{N}$, long. $93.659^{\circ} \mathrm{W}$ ) is located on a ridge north of Cowhide Cove road, in the Cowhide Cove Recreation area on Lake Greeson, approximately $13 \mathrm{~km}$ north of Murfreesboro, Pike County, Arkansas, U.S.A. The prospect is on the lower part of the southern flank of east-west-trending
Skeleton Mountain; it is situated in the Stanley Formation, and quite possibly within the Jackfork Sandstone member. The pale grey sandstone seems to have been metamorphosed to quartzite. Reed \& Wells (1938) reported that the rocks strike north $80^{\circ}$ east and dip $75^{\circ}$ south, and that the fractures in the sandstone strike north $20^{\circ}$ east and dip $60^{\circ}$ southeast.

The principal $\mathrm{Hg}$-bearing mineral at the locality is cinnabar, which occurs as fracture fillings and as disseminated grains in the sandstone (Clardy \& Bush 1976); other Hg-bearing phases (visually identified, but not necessarily confirmed by modern mineralogical techniques) include calomel, eglestonite, native mercury, metacinnabar, montroydite and terlinguaite. Artsmithite should be considered very rare; only a few micromount specimens have been recovered from the locality. On the holotype specimen, artsmithite is associated with subhedral to euhedral mm-sized quartz crystals that are, in part, stained with orange goethite, micropatches of irregularly dispersed cinnabar, and pale orange to pale yellow to colorless micaceous crusts of dickite. Additional accessory minerals reported by Clardy \& Bush (1976) and amateur mineralogists include barite, calcite, fluorapatite, galena, livingstonite, perhamite, pyrite, siderite, stibiconite and stibnite.

The minerals occur primarily as fracture fillings in the Jackfork Sandstone, with cinnabar, quartz and dickite as the principal phases. These primary minerals are generally believed to be hydrothermal in origin. Cinnabar is considered to be the original source for the formation of secondary minerals of mercury in vuggy dickite at the prospect, and the frequent association of artsmithite with calomel further suggests this, as calomel is known to be a common alteration product of cinnabar. Apatite is present at the deposit and seems to predate the cinnabar, and may, therefore, be the source of the phosphate. However, there are also extensive phosphate-bearing minerals present in the underlying Arkansas Novaculite and, in addition, rich aluminum phosphate mineralization in the still deeper Big Fork Chert; as well, the area has experienced extensive thrust 
faulting. Subsequent visits to the locality in late 2002 failed to uncover significant numbers of additional specimens of artsmithite, despite an extensive search, and as such, we can only speculate on the mode of formation of this rare mineral.

\section{Physical and Optical Properties}

Artsmithite occurs on the holotype specimen as a colorless-to-white matted nest of randomly scattered fibrous to acicular crystals that occupies an area of approximately $3 \times 1 \mathrm{~mm}$ in size and is located beside a quartz-lined cavity (Fig. 1). Individual flexible needles are elongate along [001], have no discernable crystal forms, and have a length-to-width ratio in excess of 100:1. These needles may exceed $1 \mathrm{~mm}$ in length, but the average length is about $0.5 \mathrm{~mm}$. Artsmithite is colorless, transparent with a vitreous luster, and has an offwhite to cream-colored streak. It has no obvious cleavage, has an irregular fracture, and is nonfluorescent under both long- and short-wave ultraviolet radiation. Neither the hardness nor the density could be determined because of the small size of the individual crystals. The density, calculated on the basis of the formula and unit-cell parameters derived from an investigation of the crystal structure, is $6.40 \mathrm{~g} / \mathrm{cm}^{3}$.

Optically, the fibers of artsmithite are colorless with a very low birefringence; they show parallel extinction, and are length-slow with $Z \approx c$. The mineral is biaxial positive, $2 \mathrm{~V}$ (meas.) is approximately $60^{\circ}$, and the dispersion is distinct, with $r<v$. All indices of refraction are greater than 1.80. Gladstone-Dale calculations, using the formula and unit-cell parameters determined from the crystal-structure analysis, indicate that $\bar{n}$ (calc.) is either 1.94 or 1.99 , depending on the $k$ value used for $\mathrm{Hg}_{2} \mathrm{O}$.

\section{X-Ray Crystallography}

An acicular needle of artsmithite, $0.18 \times 0.014 \times$ $0.022 \mathrm{~mm}$ in size, was investigated with a precession camera and a Bruker $P 4$ four-circle diffractometer equipped with a CCD detector. Precession photographs taken down the $b$ axis (for $k=2 n+1$ ) show extensive streaking on alternate levels along $c^{*}$, consistent with an OD (order-disorder) structure. The ordered part of the diffraction pattern shows systematic absences consistent with the space groups $C 2 / c$ and $C c$; the structure was successfully solved and refined in $C 2 / c$. The measured unit-cell parameters from the structure analysis

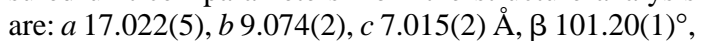
$V$ 1062.9(8) $\AA^{3}, a: b: c$ 1.8759:1:0.7731. An article on the crystal structure of artsmithite is in preparation.

The unit-cell parameters, $a$ 17.007(7), $b$ 9.070(4), $c$ 7.013(5) $\AA$, $\beta 101.30(5)^{\circ}, V 1060.9(9) \AA^{3}, a: b: c$ 1.8751:1:0.7732, $Z=4$, were refined from 20 powder reflections, representing $d$ values between 4.739 and $1.814 \AA$ for which unambiguous indexing was possible

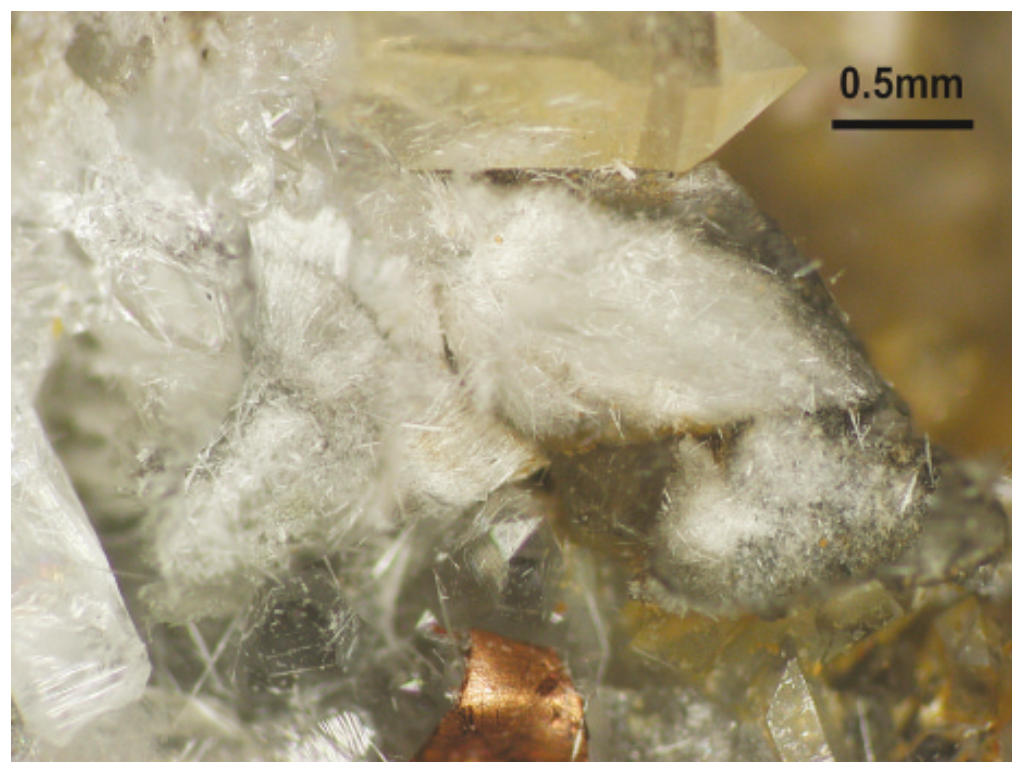

FIG. 1. Photomicrograph of the main matted nest of artsmithite on the holotype specimen. Scale bar: $0.5 \mathrm{~mm}$. 


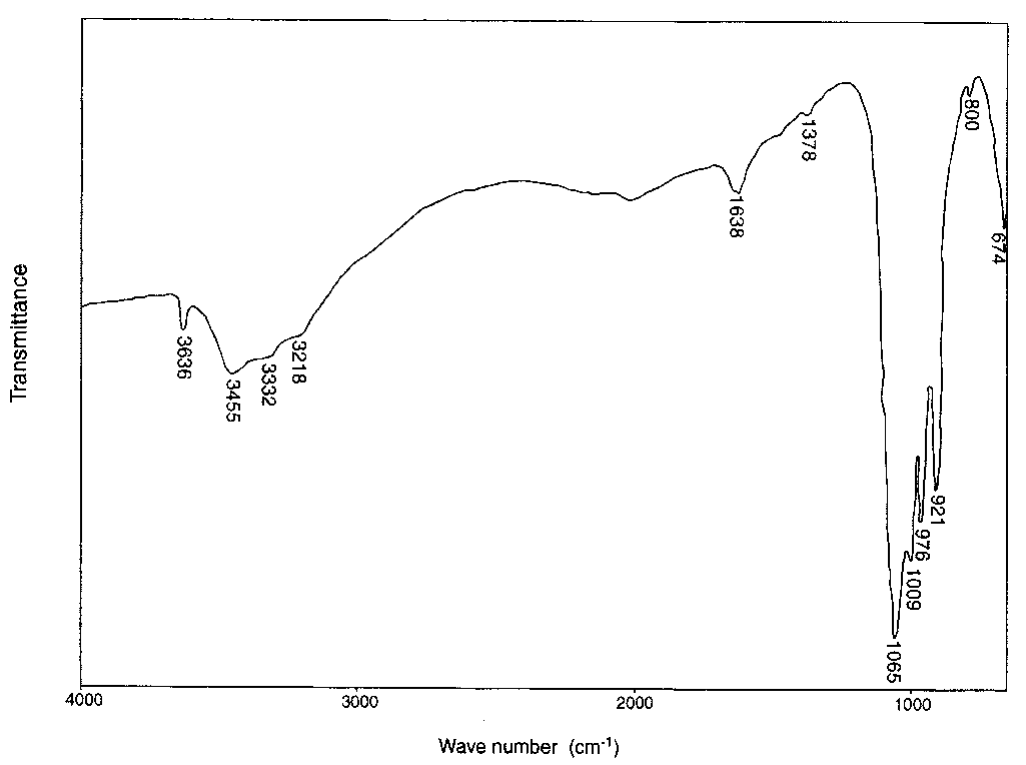

FIG. 2. Infrared-absorption spectrum for artsmithite.

on the basis of the calculated intensities derived from the crystal structure. A fully indexed powder pattern is presented in Table 1 . The powder data are unique and bear no resemblance to any other inorganic phase listed in the Powder Diffraction File. This is the first reported mercury aluminum phosphate (hydrated or otherwise) in either natural or synthetic form.

\section{Chemical Composition}

The mineral was analyzed with a JEOL 733 electron microprobe (using Tracor Northern 5500 and 5600 automation), using an operating voltage of $15 \mathrm{kV}$, a beam current of $20 \mathrm{nA}$, and a beam diameter of $20 \mu \mathrm{m}$. Data reduction was performed with a PAP routine in XMAQNT (C. Davidson, CSIRO, pers. commun.). The following standards were used: cinnabar $(\mathrm{Hg})$, simpsonite (Al) and apatite (P). A 100-s energy-dispersion scan showed no elements other than those reported; $\mathrm{F}$ was sought, but is below detection limits. The valence state for $\mathrm{Hg}$, as well as the number of $\mathrm{O}$ atoms, were determined by crystal-structure analysis prior to final interpretation of the electron-microprobe results. The paucity of material prevented quantitative determination of the amount of $\mathrm{H}_{2} \mathrm{O}$. However, the presence of $\mathrm{H}$ as $(\mathrm{OH})$ was confirmed both by crystal-structure analysis and by powder infrared-absorption study; the amount of $\mathrm{H}_{2} \mathrm{O}$ was therefore calculated by stoichiometry. Crystal size and morphology made sample preparation in polished section extremely difficult. Only one area 20 $\mu \mathrm{m}$ across was available for quantitative analysis, and therefore only one analysis was done. It gave the fol-
TABLF 1. X-RAY POWDFR-DIFFRACTION DATA FOR ARTSMITHITE

\begin{tabular}{|c|c|c|c|c|c|c|c|}
\hline$I_{\text {est }}$ & $d_{\text {meas }}$ & $d_{\mathrm{calc}}$ & $h k t$ & $I_{\text {est }}$ & $d_{\text {meas }}$ & $d_{\mathrm{caic}}$ & $h k l$ \\
\hline 100 & 8.326 & 8.339 & 200 & * 10 & 2.187 & 2.188 & 240 \\
\hline 20 & 5.480 & 5.465 & 111 & * 5 & 2.156 & 2.154 & 041 \\
\hline * 50 & 4.739 & 4.740 & 310 & * & 2.086 & 2.085 & 800 \\
\hline * 40 & 4.166 & 4. 169 & 400 & 3 & 2.050 & 2.055 & 241 \\
\hline * 5 & 3.641 & 3.630 & 311 & 5 & 2.013 & 2.013 & 332 \\
\hline * 30 & 3.443 & 3.439 & 002 & & & 2.001 & $\overline{5} 32$ \\
\hline * 15 & 3.273 & 3.270 & $\overline{1} 12$ & 5 & 1.992 & 1.992 & 440 \\
\hline * 10 & 3.134 & 3.131 & 510 & & & 1.980 & 602 \\
\hline * 5 & 3.058 & 3.055 & 112 & 3 & 1.957 & 1.961 & $\overline{8} 02$ \\
\hline * 80 & 2.979 & 2.980 & 202 & 5 & 1891 & 1.893 & 042 \\
\hline * 50 & 2.952 & 2.952 & $\overline{4} 02$ & 2 & 1.891 & 1.891 & $\overline{2} 42$ \\
\hline * 80 & 2.784 & 2.780 & 600 & 3 & 1.872 & 1.871 & 730 \\
\hline * 75 & 2.660 & 2.656 & 330 & 3 & 1.838 & 1.845 & $\overline{9} 11$ \\
\hline 3 & 2.555 & 2.559 & $\overline{3} 31$ & * 10 & 1.814 & 1.816 & 910 \\
\hline * 5 & 2.428 & 2.429 & 402 & & & 1.805 & 242 \\
\hline * 5 & 2.404 & 2.404 & $\overline{602}$ & 20 & 1.803 & 1.798 & $\overline{4} 42$ \\
\hline * 10 & 2.288 & 2.290 & $\overline{1} 32$ & 3 & 1.767 & 1.766 & 712 \\
\hline * 15 & 2.265 & 2.268 & 040 & & & 1.761 & $\overline{7} 32$ \\
\hline \multirow{2}{*}{3} & \multirow{2}{*}{2.208} & 2.212 & 132 & \multirow[t]{2}{*}{50} & \multirow[t]{2}{*}{1.755} & 1.757 & 640 \\
\hline & & 2.204 & $\overline{3} 32$ & & & 1.753 & $\overrightarrow{204}$ \\
\hline
\end{tabular}

$114.6 \mathrm{~mm}$ Debyc-Scherrer powder camera, Cu radiation, Ni-filter ( $\lambda \mathrm{CuK \alpha}=1.54178$ A). Intensities estimated visually. Not corrected for shrinkage, and no internal standard used. *: lines used for unit-cell refinement. Indexed on $a 17.007(7), b$ $9.070(4), c 7.013(5) \AA, \beta 101.30(5)^{\circ}$. Values of $d_{\text {meas }}$ and $d_{\text {casc }}$ are expressed in $\AA$.

lowing: $\mathrm{Hg}_{2} \mathrm{O}$ 78.28, $\mathrm{Al}_{2} \mathrm{O}_{3}$ 5.02, $\mathrm{P}_{2} \mathrm{O}_{5}$ 11.39, $\mathrm{H}_{2} \mathrm{O}$ [1.63], total [96.32] wt. \%. With $\mathrm{O}=8.74$ and $(\mathrm{OH})=$ 1.78 (from the crystal-structure analysis), the empirical formula is $\mathrm{Hg}^{1+}{ }_{4.00} \mathrm{Al}_{1.05} \mathrm{P}_{1.71} \mathrm{O}_{8.74} \mathrm{H}_{1.78}$. The formula derived from crystal-structure analysis, $\mathrm{Hg}^{1+}{ }_{4} \mathrm{Al}$ $\left(\mathrm{PO}_{4}\right)_{1.74}(\mathrm{OH})_{1.78}$, requires $\mathrm{Hg}_{2} \mathrm{O} 81.41, \mathrm{Al}_{2} \mathrm{O}_{3} 4.97$, $\mathrm{P}_{2} \mathrm{O}_{5} 12.05, \mathrm{H}_{2} \mathrm{O} 1.56$, total 99.99 wt.\%. The general 
formula for artsmithite is $\mathrm{Hg}^{1+}{ }_{4} \mathrm{Al}\left(\mathrm{PO}_{4}\right)_{2-x}(\mathrm{OH})_{1+3 x}$, where $x=0.26$ for the crystal structure determined here. Because precise values of the indices of refraction could not be determined, a meaningful index of compatibility could not be calculated.

\section{INFRARED SPECTROSCOPY}

The procedures for acquiring the infrared-absorption spectrum of artsmithite are identical to those reported by Roberts et al. (1994). The sample was analyzed using a Bomem Michelson MB-100 FTIR spectrometer equipped with a wide-band mercury-cadmium telluride detector. The transmittance spectrum (Fig. 2) shows a number of medium-intensity absorption bands, 3218 (shoulder), 3332 (shoulder), 3455 (peak) and 3636 $\mathrm{cm}^{-1}$ (peak), attributable to O-H stretching in hydroxyl groups, and a weak absorption band, centered at $1638 \mathrm{~cm}^{-1}$, characteristic of $\mathrm{H}-\mathrm{O}-\mathrm{H}$ bending in adsorbed $\left(\mathrm{H}_{2} \mathrm{O}\right)$. Characteristic bands for phosphate are very strong and are centered at 1065, 1009, 976 and $921 \mathrm{~cm}^{-1}$.

\section{ACKNOWLEDGEMENTS}

The authors thank E. Moffatt (Canadian Conservation Institute) for the infrared spectrum of artsmithite, P. Hunt (GSC) for the photomicrograph reproduced in
Figure 1, M. Clarke (GSC) for redrafting Figure 2, K. Mooney (GSC) for typing the manuscript, and Drs. M. Raudsepp, A.M. McDonald, J.A. Mandarino and R.F. Martin for comments and corrections, which greatly improved the final version of this manuscript. FCH was supported by a Canada Research Chair in Crystallography and Mineralogy, and by Discovery and Major Equipment grants from the Natural Sciences and Engineering Research Council of Canada.

\section{REFERENCES}

Clardy, B.F. \& Bush, W.V. (1976): Mercury district of southwest Arkansas. Arkansas Geol. Commission, Inform. Circ. 23.

REED, J.C. \& WELLS, F.G. (1938): Geology and ore deposits of the southwestern Arkansas quicksilver district. U.S. Geol. Surv., Bull. 886-C, 15-90.

Roberts, A.C., Ercit, T.S., Criddle, A.J., Jones, G.C., Williams, R.S., CuREton, F.F., II \& JENSEN, M.C. (1994): Mcalpineite, $\mathrm{Cu}_{3} \mathrm{TeO}_{6} \bullet \mathrm{H}_{2} \mathrm{O}$, a new mineral from the McAlpine mine, Tuolumne County, California and from the Centennial Eureka mine, Juab County, Utah. Mineral. Mag. 58, 417-424.

Received January 15, 2003, revised manuscript accepted April 12,2003 